\title{
Potential U.S. Consequences of China's Capital Account Liberalization
}

\author{
Ana Maria Santacreu, Economist \\ Usa Kerdnunvong, Senior Research Associate
}

$\mathrm{n}$ recent years, the United States has had positive net international income (e.g., stock dividends and bond coupon payments) despite being a net debtor to China. China, however, has had negative net income, despite being a lender to the United States. Recent policy changes in China could end this trend.

Eswar Prasad recently analyzed China's efforts to expand the renminbi's (RMB) role in the global monetary system. ${ }^{1}$ China has been promoting the international use of its currency by (i) permitting settlement of trade transactions in $\mathrm{RMB}$, (ii) allowing issuance of RMB-denominated bonds in Hong Kong, (iii) permitting offshore RMB deposit accounts and creating offshore RMB centers, and (iv) facilitating cross-border RMB transactions. Prasad concludes that, as a result, the RMB will increase its role in global trade and finance and is on the path to becoming an international reserve currency.

\section{Recent policies in China could change the structure of capital flows from China to the United States.}

This internationalization of capital accounts will allow Chinese households, firms, and institutional investors to diversify their portfolios and invest in international markets. As a result, the structure of capital flows from China to the United States will change from official purchases of U.S. Treasury securities by the Chinese government to private investment, such as through foreign direct investment and purchases of debt and equity portfolios.

In this essay, we study the net external position ${ }^{2}$ of the United States and China from the mid-2000s to explain why Chinese residents are buying foreign assets.

Since 2005, the United States has accumulated a current account deficit, while China has accumulated a current account surplus. ${ }^{3}$ Panels $A$ and $B$ of the figure show the current accounts (as a percent of GDP) for the two coun- tries. The accumulated U.S. current account deficit implies that the United States has been importing more goods and services than it exports, hence it has been exporting more financial assets-claims on future income. In other words, the United States has become a net borrower from the rest of the world because it has run a persistent current account deficit. The opposite is true for China. With a current account surplus, China is a net lender to the rest of the world, mainly the United States, which is reflected in its positive net foreign position (Panel C). In other words, China has been financing the U.S. current account deficit by buying U.S. assets.

A country's net external position is determined by its accumulated current account deficits and surpluses and by changes in the domestic-currency value of its assets and liabilities. A closer look at the composition of the net foreign asset positions of the two countries reveals the following: Even though the United States is a net borrower, its net income has been positive and increasing (Panel D). That is, the return it has been receiving from its assets is higher than the return that it has been paying for its liabilities (i.e., it has had a positive net international investment flow). China's net international investment flow, however, reveals the opposite: China has been paying a higher return from its liabilities than it has been receiving from its external assets (Panel C).

Lane and Milesi-Ferretti ${ }^{4}$ show that U.S.-owned assets consist mainly of portfolio equity and derivatives that pay higher returns than its liabilities, which are mainly U.S. Treasury bills. Gourinchas and Rey ${ }^{5}$ call this difference the "exorbitant privilege": Because the U.S. dollar is perceived as a low-risk currency, the U.S. return from external assets is higher than the return it pays for external liabilities. Most of China's assets are sovereign bonds from low-risk countries, such as the United States, which pay a low return, whereas its liabilities are mainly foreign direct investment in China, which is riskier and pays a higher return. As a result, China has a negative net international investment flow despite being a net lender. 


\section{A. China: Current Account}

Percent of GDP

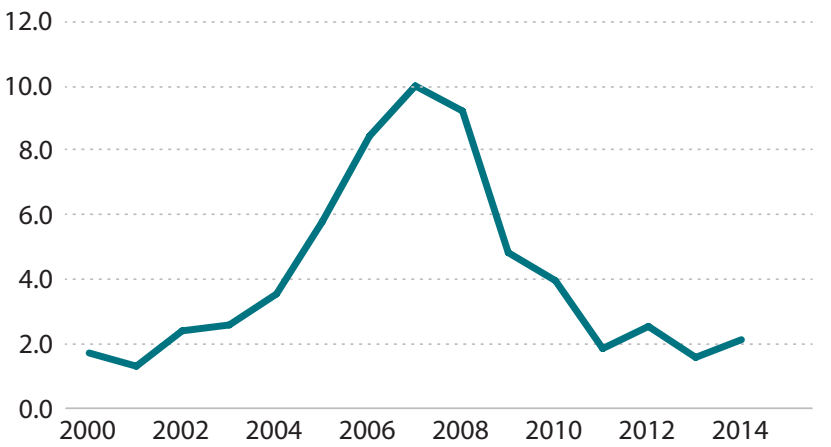

\section{Net Foreign Asset Position and Net International Investment Flows in China}

Percent of GDP Percent of GDP

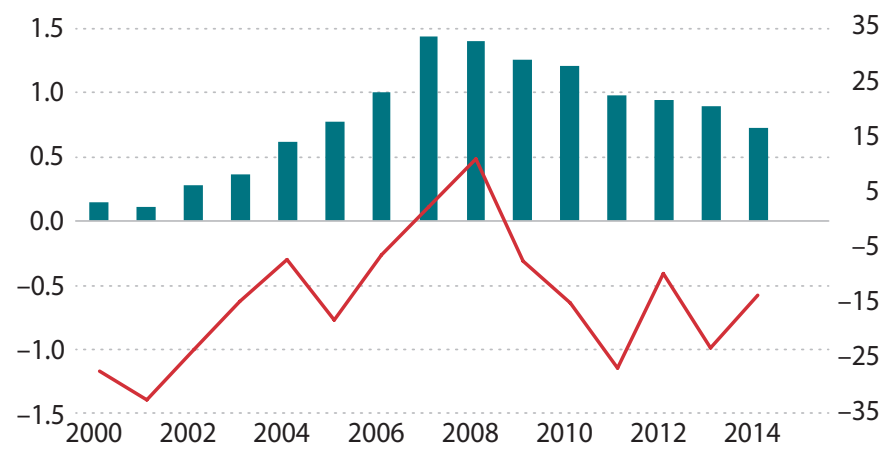

\section{B. U.S.: Current Account}

Percent of GDP

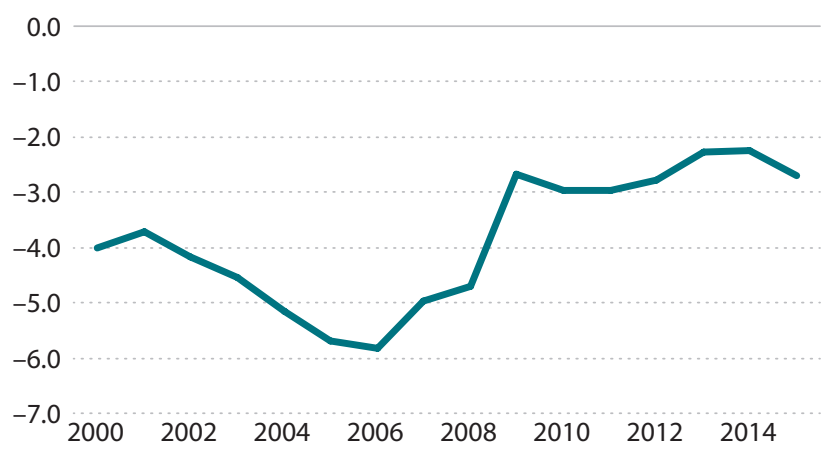

\section{Net Foreign Asset Position and Net International Investment} Flows in the U.S.

Percent of GDP Percent of GDP

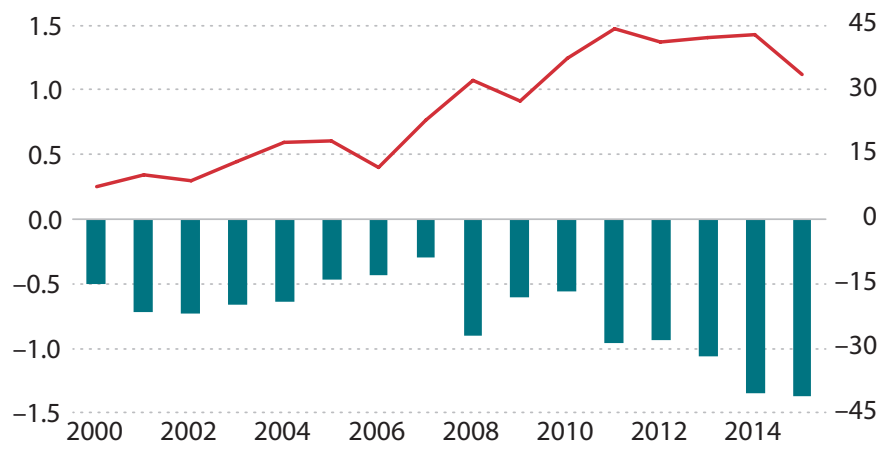

- Net Foreign Assets (right axis)

NOTE: In Panel C, data used to calculate net foreign assets prior to 2004 are from the updated "External Wealth of Nations" dataset by Lane and Milesi-Ferretti (2007; see footnote 4). SOURCE: IMF Balance of Payments, IMF International Financial Statistics, Lane and Milesi-Ferretti (2007), and authors' calculations.

By allowing the purchase of foreign assets, China may reverse the sign of its net international income flow; that is, it could start earning higher returns than those paid by safe but low-yield bonds. This shift could reduce China's currency risk if the U.S. dollar depreciates. If it also reduces official purchases of U.S. assets, the yield the United States must pay on those assets may increase slightly.

\section{Notes}

1 Prasad, Eswar. "China's Efforts to Expand the International Use of the Renminbi." U.S.-China Economic and Security Review Commission, February 2016.

2 A country's net external position is the nation's stock of external (foreign) assets less its stock of external liabilities.

\begin{abstract}
${ }^{3}$ The net current account is a nation's savings less its investment. It is the sum of net exports (exports less imports), net primary income, and net secondary income. A current account surplus is when the nation is a net lender to the rest of the world, and a current account deficit is when the nation is a net borrower from the rest of the world.

${ }^{4}$ Lane, Philip R. and Milesi-Ferretti, Gian Maria. "The External Wealth of Nations Mark II: Revised and Extended Estimates of Foreign Assets and Liabilities, 1970-2004." Journal of International Economics, November 2007, 73(2), pp. 223-50.

5 Gourinchas, Pierre-Olivier and Rey, Helene. "From World Banker to World Venture Capitalist: US External Adjustment and the Exorbitant Privilege," in Richard H. Clarida, ed., G-7 Current Account Imbalances: Sustainability and Adjustment. Chicago: University of Chicago Press, 2007, pp. 11-55.
\end{abstract}

